\title{
Viable but Nonculturable Bacteria in Food
}

\author{
Marco Sebastiano Nicolò and Salvatore Pietro Paolo Guglielmino \\ University of Messina \\ Italy
}

\section{Introduction}

"Dis-moi ce que tu manges, je te dirai ce que tu es." (Tell me what you eat and I will tell you what you are - Anthelme Brillat-Savarin, Physiologie du Goût, ou Méditations de Gastronomie Transcendante, 1826)

"Ninety per cent of the diseases known to man are caused by cheap foodstuffs. You are what you eat." (Victor Lindlahr, 1923)

In every time, availability of food has been a struggle for human survival. In particular, food storage techniques and maintaining have represented one of the most important milestones in the evolution and development of human society. In that sense, the use of fire for cooking and salt and spices for conservation have been important discoveries in food processing, with immediate consequences on human habits and life.

Nowadays, food resources remain a primary objective for human society, specifically in terms of safety and control.

In fact, up to date more than 250 foodborne diseases have been described.

Infectious foodborne diseases are caused by the consumption of food contaminated by pathogen bacteria, viruses, parasites and prions.

Contamination may occur as consequence of incorrect practices at different steps of food processing, such as handling of feedstock, decontamination, packaging and storage.

The rapid globalization and trade among countries with different hygienic standards have increased the possibility of food contamination. Hence, outbreaks of foodborne diseases that were once contained within a small community may now take place on global dimensions.

The fundamental strategy for outbreaks monitoring is the traceability, that is the possibility to identify the pathogen(s), the ways of food contamination and the spreading.

One of the most critical problems in traceability of bacterial pathogens is represented by a state of latency of most foodborne bacterial species, called "viable but nonculturable (VBNC) state", induced by environmental stresses, such as low temperature, high osmolarity, and nutrient starvation.

In such a state, bacteria show a discrete metabolic activity, but are not able to replicate.

Following environmental stimuli, as temperature shift or replenishment of nutrients, VBNC bacteria can "resuscitate", so restoring their ability to grow on common culture media. 
Still open is the debate about the possibility, for pathogen bacteria in VBNC state, to maintain pathogenicity and trigger disease in their hosts.

The evidence of contrasting results, in fact, indicates the need for a better understanding of such complex phenomenon, particularly about the underlying molecular network.

Several studies have shown that the most of human pathogens, especially foodborne bacteria, may enter VBNC state as survival strategy against environmental stress.

Many chemo-physical characteristics in food (as acidic $\mathrm{pH}$, low content in carbohydrates, etc.), as well as processing, decontamination and storage, may induce VBNC state.

The observation of VBNC forms of foodborne bacteria and the lack of a ultimate information about the possibility for VBNC bacteria to retain their virulence has raised the problem about the necessity of new procedures for VBNC detection in food.

Many systems have been proposed for VBNC detection in water, but their application on food seems to be quite difficult. In fact, factors as food texture and $\mathrm{pH}$, as well as presence of free lytic enzymes and other compounds, may interfere with the chemical reaction(s) required for the assay.

Then, traceability of foodborne VBNC pathogens strongly requires the design of new detecting systems.

\section{The causes of infectious foodborne disease outbreaks}

Infectious foodborne diseases are caused by the consumption of food or beverages contaminated by many pathogenic bacteria, viruses, parasites and prions. In addition, contamination can also be due to molecules produced by bacteria, called toxins. Toxins can be derived from cell structure, such as lipopolysaccharide (LPS) of Gram negative bacteria (endotoxins), as well as they are synthesized inside the cell and secreted in the surrounding environment (exotoxins), as botulinum, cholera and Shiga toxins.

After food contamination, the microbe or its toxin enters the organism via the digestive tract, triggering the illness.

In general, an outbreak of foodborne disease occurs when a group of people eats the same contaminated food and two or more of them develop the same illness.

Many outbreaks consist of sporadic cases and are self-limiting, in that they are related to a small quantity of contaminated food which, usually, is totally eaten by few people and involve a specific geographic area. A sporadic outbreak may follow a catered meal or eating a meal at a restaurant on a particularly busy day.

The number of people affected and the extension of geographic areas in which a foodborne outbreak occurs have considerably increased as consequence of the variations in social habits. Commonly, workers and students may have meals at large-scale retail trade structures as canteens, highway stops, fast food chains and refectories. Such structures, usually, look to suppliers which, from the place where food is produced, distribute their products on national scale. Then, contaminated food may be transported in different places, causing many distinct outbreaks at the same time within a country. 
For example, in 2005, in South Wales an outbreak of Escherichia coli O157 occurred, with identification of 157 cases, 31 people hospitalized, and one 5-year old child died, as well as in 2008, an outbreak of listeriosis in Canada (57 clinical cases) killed 23 people.

Recently, in October 2010 an outbreak of cholera occurred in Haiti. On 18 August 2011, the total number of reported cholera cases was 419,511, with 222,359 hospitalized. Overall, data from health facilities indicate that 5,968 people have died (case fatality rate $1.4 \%$ ).

Moreover, actually it has been recognized that outbreaks may spread on wider geographic areas. In fact, the rapid globalization and trade among countries with different hygienic standards has increased the risk and entity of food contamination. As consequence, many outbreaks that were once contained within a small community may now take place on wider geographic areas and several examples can be considered.

The Bovine spongiform encephalopathy (BSE), commonly known as mad-cow disease, was firstly detected in United Kingdom and represented a world-wide crisis. The cause of global infection was attributed to the use of contaminated bone meal, used in livestock feeding. Only in the United Kingdom, 4.4 millions of cattle were slaughtered in the attempt to eradicate the pathology and limit its spreading; moreover, the European Union banned exports of British beef from March 1996 to May 2006.

In 2011, an outbreak of gastroenteritis caused by E. coli O104:H4 in Germany had several social, political and economic implications throughout whole Europe.

Often, such kind of outbreaks are very difficult to identify while occurring. An example is represented by an outbreak of Salmonella which simultaneously happened in Europe, North America and Israel, following the importation of contaminated snack food. The outbreak identification was accidental, because it was caused by a rare strain of Salmonella and the number of cases in each geographical entity was not high.

Therefore, there is a strong probability that contaminated foodstuffs distributed in different countries could origin outbreaks which are not readily pointed out by national health authorities if the spreading in each single country is limited. Many sporadic cases happening in single countries may be, then, part of a common global outbreak.

\section{The causes of food contamination}

Contamination may occur as consequence of incorrect practices at different steps of food processing, such as feedstock production and handling, food preparation, packaging and storage. Each stage of food processing shows critical points.

\subsection{Feedstock production}

Use of raw manure or sewage for fertilization and lack of hygiene and health controls in fish and cattle breeding are the first cause of contamination. Spinach and lettuce have been linked to E. coli O157:H7 outbreaks (Erickson et al., 2010). Untreated food, such as fresh fruit juice and milk, carry risks because they are not subjected to any decontaminating procedure.

Similarly, incorrect slaughterhouse practices can lead to contamination, especially when faecal or intestinal matter from cattle mixes with the meat. 


\subsection{Feedstock handling}

Handling and washing of feedstock before processing are very important sources of contamination. Handling by ill people which have cuts, open sores or skin infections causes spreading of Staphylococcus aureus, which is often found on skin with boils and blisters. That is why food handling should be performed by personnel wearing gloves. However, touching contaminated surfaces, coughing into a gloved hand or handling money before food preparation can still spread germs, which is why gloves should be changed often.

\subsection{Food preparation}

Beyond the causes of contamination above discussed, in this step cross contamination is a crucial factor. This can happen during food preparation and storage. For example, juices from raw beef and poultry could mix with ready-to-eat food or when kitchen tools are used without distinction for both raw beef and fresh vegetables. Cleaning tools with soap and hot water strongly reduces contamination.

Also undercooking can be cause of food contamination, because heat drastically reduces the presence of bacteria in food.

\subsection{Food packaging}

In food packaging, hygiene of handlers and materials employed are critical parameters.

Historically, canned food, if prepared under unsafe conditions, can be susceptible to contamination by toxinogenic microbes, such as Clostridium botulinum.

Nowadays, food packaging is mostly based on plastics, employed for vegetables, cheese, fruit. However, even if a correct packaging assures food safety from microbe contamination and remarkably prolongs shelf-life, much attention has to be paid about hygienic requirements. Bacteria can colonize and adhere on plastics, producing biofilms which may reduce shelf life or, for pathogenic bacteria, they may secrete toxins or proliferate on food.

\subsection{Food storage}

This is a critical step for perishable food which requires refrigeration or freezing, because low temperature slows down bacterial reproduction, even if some species, called psycrophiles, such as Listeria monocytogenes, Yersinia enterocolitica and Pseudomonas sp., are able to develop also at refrigerator temperature.

Food storage has become increasingly important in the perspective of globalization, in that different food tipologies may be transported together. Physical contact and dripping of juices to other foodstuffs are causes of crosscontamination. In this way, one kind of food can be contaminated by unusual bacteria, that become difficult to be identified. Also changes in livestock farming and industrialization of slaughtering of pigs have played an important role. Transportation of live animals for slaughtering has in some studies been proved to be an important factor in dissemination of $Y$. enterocolitica from farm to farm (Nesbakken, 2007). 


\section{Foodborne bacteria}

Bacteria are single-cell microrganisms colonizing any environment. From an ecological point of view, they play a pivotal role in the biogeochemical cycles, by which chemical elements move from living to non-living matter and vice versa. Some of them produce molecules which improve the quality of human life, such as antibiotics, vitamins, probiotics and other nutritional factors.

In food industry, several Lactobacillus species are very important for production of cheese, yogurt, beer, cider, wine, bread and chocolate, as well as in functional food.

Several bacteria inhabit the skin and the intestine of animals and humans, protecting them from contamination by hazardous microbes and playing a role in metabolism.

Pathogen bacteria are responsible for infectious diseases, by colonization of tissues and organs, whose physiology is altered by bacterial metabolism and reproduction.

Foodborne pathogen bacteria are a group of microrganisms which can contaminate food and, after swallowing, cause illness.

Common symptoms of foodborne illness are diarrhoea and/or vomiting, abdominal cramps, nausea, fever, joint/back aches, and fatigue.

A description of the most common known foodborne pathogen bacteria and related illness(es) follows. Intriguingly, for the most of them, the VBNC state has been described.

\section{Bacillus cereus}

Gram positive rod-shaped bacterium, able to form endospores under negative conditions, commonly found in soil and vegetation. After pasteurisation or heating, endospores survive, whereas competing microflora is eliminated. During food cooling, endospores germinate and vegetative cells proliferate, producing several toxins, one of which is highly resistant to heat and to $\mathrm{pH}$ between 2 and 11. The infection may be almost diarrhoeal, but some cases described nausea and vomiting. The illness is self-limiting.

\section{Brucella spp.}

Genus of gram negative, aerobic, rod-spherical shaped bacteria which infect animals and humans. Four species are recognised as harmful, that is B. abortus (from cattle), B. melitensis (from goats, sheep, and camels), B. suis (from pigs), and B. canis (from dogs).

It can contaminate raw milk and cheese, but may be acquired also by inhalation, causing brucellosis, also known as Malta fever, undulant fever, Rock of Gibraltar fever, and Bang's disease.

The symptoms are non-specific and systemic, with fever, sweats, headache, anorexia, back pain. The chronic form causes suppurative lesions in the liver, spleen, and bone, with a mortality of $5 \%$ in untreated individuals.

\section{Campylobacter jejuni}

Gram negative, microaerophilic, spirally curved bacterium, commonly living in the bowel of animals, especially in poultry, and spread by faeces and milk. 
It can also contaminate incorrectly prepared meat and poultry.

It is one of the first cause of foodborne illness (campylobacteriosis) in United States and in United Kingdom. Symptoms of campylobacteriosis are fever, cramping abdominal pain and diarrhoea. Remission follows within a week.

\section{Clostridium botulinum}

Gram positive rod-shaped bacterium, obligate anaerobe, which forms endospores in presence of oxygen or other environmental stresses. Food contamination can occur due to improperly preserved or home-canned, low-acid food, which allows endospore germination and subsequent toxin secretion. Among the toxins, seven are neurotoxins, that cause the flaccid muscular paralysis by inhibition of neuromuscular transmission through decreased acetylcholine release. Death occurs when respiratory mechanics is compromised.

\section{Clostridium perfringens}

Gram positive rod-shaped bacterium, obligate anaerobe, which forms endospores in presence of oxygen or other environmental stresses. Preferentially, it contaminates meatbased food, because aminoacid content satisfies its nutritional requirements. After cooking, oxygen concentration is lowered and endospores germinate during cooling. Storage time and refrigeration are critical, in that the vegetative cell can duplicate in 20 minutes. After ingestion, in the bowel the bacterium produces an exotoxin which causes abdominal pain and diarrhoea. In the most of cases, the illness is self-limiting.

\section{Corynebacterium ulcerans}

Gram-positive, nonmotile, straight to slightly curved rod-shaped bacterium that causes subacute bovine mastitis, but C. ulcerans has increasingly been isolated from domestic animals such as dogs and cats.

Consumption of raw milk and dairy products or contact with cattle may cause infection of humans, causing a disease very similar to diphtheria by secretion of a toxin which inhibits protein synthesis of epithelial cells, leading them to death.

Symptoms are sore throat, low fever, and a pseudomembrane on the upper respiratory tract.

Toxin may spread through the bloodstream and can lead to life-threatening complications in heart and kidneys. It can also cause nerve damage, eventually leading to paralysis. $40 \%$ to $50 \%$ of those left untreated can die.

\section{Coxiella burnetii}

C. burnetii is an obligate intracellular, small Gram-negative bacterium highly resistant to high temperature, osmotic pressure, ultraviolet light.

It can contaminate people after ingestion of raw milk or contact with infected animals.

C. burnetii is highly infectious via the respiratory route, but the infectivity via the oral route is poorly understood. It has been proposed that C. burnetii can escape the gastrointestinal tract and produce infection sufficient to stimulate systemic immunity (Loftis et al., 2010). 
C. burnetii secretes a toxin inside the phagolysosome which inhibits its fusion with the cell degradation endosomes.

In humans it causes the $\mathbf{Q}$ fever, with fever, severe headache, muscle and joint pains, upper respiratory problems and gastro-intestinal symptoms such as nausea, vomiting and diarrhoea. Life threatening complications are acute respiratory distress syndrome (ARDS), granulomatous hepatitis and retinal vasculitis.

The chronic form of $Q$ fever is virtually identical to endocarditis. It is usually fatal if untreated; however, with appropriate treatment the mortality falls to around $10 \%$.

\section{Escherichia coli}

Gram negative, rod-shaped bacterium, inhabitant of mammal bowel. Among the pathogenic strains, distinct groups can be identified.

- Enterotoxigenic (ETEC) E. coli produces and releases two exotoxins, LT (heat-labile) enterotoxin, similar to cholera toxin, and ST enterotoxin, which causes CGMP accumulation in the target cells and a subsequent secretion of fluid and electrolytes into the intestinal lumen. Both toxins induce watery diarrhoea, similarly to cholera. It is responsible of the majority of "traveller's diarrhoea" and infant diarrhoea in developing countries.

- Enteroinvasive (EIEC) E. coli can invade the intestinal wall, giving inflammation, fever and diarrhoea similar to Shigella-like dysentery.

- Among the enterohaemorrhagic (EHEC) E. coli strains, the most important is the well known serotype O157:H7. EHEC strains produce Shiga-like toxins, which induce haemorrhagic colitis, resulting in bloody diarrhoea. Sometimes the toxin may spread in kidney, causing a very dangerous complication called haemolytic uraemic syndrome. The first symptom is the presence of blood in urine leading to kidney failure.

- Enteropathogenic (EPEC) strains use an adhesin known as intimin to bind host intestinal cells. Adherence to the intestinal mucosa causes a rearrangement of actin in the host cell, causing significant deformation. EPEC cells are moderately invasive and elicit an inflammatory response. Changes in intestinal cell ultrastructure are likely the prime cause of diarrhoea in those afflicted with EPEC.

- Enteroaggregative (EAEC) strains have fimbriae which aggregate tissue culture cells. EAEC strains bind to the intestinal mucosa to cause watery diarrhoea without fever and are not invasive. They produce a haemolysin and a ST enterotoxin similar to that of ETEC strains.

\section{Helicobacter pylori}

Gram negative, spiral-shaped microaerophilic bacterium, normally colonising the stomach of $30-50 \%$ of the human population in developed countries.

The ways of transmission are likely to be oral and oro-faecal routes, even if it has been quite difficult its isolation by the faeces (Thomas et al., 1992; Kelly et al., 1994).

In the stomach, the bacterium secretes the enzyme urease, which degrades urea to ammonia. Ammonia lowers the $\mathrm{pH}$ locally, so permitting the development of the infection.

It is responsible of chronic gastritis, peptic ulcer disease and stomach cancer. Actually, it is also associated with the gastric MALT lymphoma and its role on other several illnesses, as Sjögren, Prader-Willy and Raynaud syndromes, is matter of discussion. 


\section{Listeria monocytogenes}

Gram positive, facultative anaerobe, rod-shaped intracellular bacterium, commonly spread in soil and water. Vegetables are contaminated by the soil or by manure used as fertilizer. Animals can carry the bacterium asymptomatically and can contaminate food, such as uncooked meat, raw milk and soft cheeses, that are usually prohibited to pregnant women.

It is the causative agent of listeriosis. After having entered immune system cells, it becomes septicemic and can grow. The intracellular state in phagocytic cells may permit access to the brain and probably to reach the fetus in pregnant women by crossing the placenta.

Listeriosis may arise as septicaemia, meningoencephalitis, corneal ulcer, pneumonia and during pregnancy (causing abortion within 6-9 months or stillbirth).

When no internalization in cells occurs, the disease is presented as a febrile gastroenteritis.

L. monocytogenes is the leading cause of death among foodborne bacterial pathogens, with 20 to 30 percent of clinical infections resulting in death.

\section{Plesiomonas shigelloides}

Gram-negative, rod-shaped bacterium, which has been isolated from freshwater, freshwater fish, and shellfish and from many types of animals including cattle in tropical and subtropical areas.

Common symptoms are fever, shivers, abdominal pain, nausea, diarrhoea (which, in severe cases, may be greenish-yellow, foamy, and bloody) or vomiting and appear 20-24 hours after consumption of contaminated food or water.

$P$. shigelloides gastroenteritis is usually a mild self-limiting disease with remission in healthy people within 1-7 days, described in African countries, but sporadic cases have been reported also in Europe and North America. Severe forms may include sepsis and meningoencephalitis in newborns, arthritis, cholecystitis and osteomyelitis (Terpeluk, 1992).

\section{Salmonella spp.}

The genus Salmonella consists of Gram negative, rod-shaped facultatively anaerobe bacteria, which live in the bowel of humans and animals.

Meat, poultry and eggs are the most common food contaminated by Salmonella. However, food is contaminated by low loads of Salmonella, which are quite difficult to be appreciated by standard detection methods.

All species are considered pathogenic and responsible for a gastroenteritis known as salmonellosis. Bacteria reach the bowel and duplicate. Sometimes, they may cross the mucosa, entering lymphatic and cardiovascular systems; from there, they may infect other organs, causing septicaemia.

Symptoms are moderate fever, nausea, abdominal pain and cramps, diarrhoea. Average mortality rate is below $1 \%$, but increases in children and old people, occurring as septicaemia.

Among the species, S. typhi is the most virulent. It is the aetiological agent of typhoid fever and is spread only by human faeces. Symptoms are high fever $\left(40^{\circ} \mathrm{C}\right)$ and continued 
headache, then diarrhoea appears and fever declines. Differently from salmonellosis, bacteria multiply into phagocytic cells and disseminate in the body. In severe cases, perforation of bowel mucosa may occur.

Today, the mortality rate of typhoid fever is about $1-2 \%$; in the past it exceeded also $10 \%$.

\section{Shigella spp.}

The genus Shigella is composed of Gram negative, rod-shaped bacteria, which are normally present in the bowel of humans, apes and monkeys.

Food contamination occurs via handling by unhealthy operators. Four species are pathogenic: S. sonnei, S. dysenteriae, S. flexneri and S. boydii. Many cases of "traveller's diarrhoea" are supported by Shigella spp.

S. dysenteriae causes severe dysentery and prostration by secreting the "Shiga toxin", which inhibits protein synthesis in epithelial cells of intestinal wall, killing them. Bacteria multiply in the small intestine and spread in the large intestin, entering the epithelial cells. Infection proceeds towards neighbouring cells, via a "cell-to-cell" mechanism, thus avoiding immune system response. As consequence, intestinal mucosa is damaged, causing severe diarrhoea with blood and mucus in the faeces. Additional symptoms may be abdominal cramps and fever.

Only $S$. dysenteriae may reach the bloodstream, causing septicaemia. Its mortality rate is quite significant and may reach $20 \%$ in tropical areas, where it is prevalent.

\section{Staphylococcus aureus}

Gram positive, spherical-shaped bacterium, it is a frequent inhabitant of respiratory tract from which it can contaminate hands and skin. Typically, S. aureus and others staphylococcal species are resistant to various stresses. They can survive $60^{\circ} \mathrm{C}$ for 30 minutes, drying and high osmotic pressures. Such characteristics allow their survival under conditions that, generally, eliminate the most of bacteria. In absence of competitors, then, it can rapidly proliferate.

It is able to produce several toxins that improve the virulence or damage tissues, but the toxin produced by serogroup A is responsible for most of the cases. The toxin is heat-stable, in that maintains its virulence up to 30 minutes of boiling.

Symptoms of intoxication are vomiting and abdominal cramps followed by diarrhoea. Remission is reached within 24 hours.

\section{Streptococcus spp.}

Genus of gram positive, microaerophilic, spherical-shaped bacteria which occur in chains or pairs. The genus is defined by a combination of antigenic, haemolytic, and physiological characteristics into Groups A, B, C, D, F, and G.

Groups A and D can be transmitted to humans via food.

Group A is formed by a single species, S. pyogenes, with 40 antigenic types, while Group D is represented by the new genus Enterococcus. 
Many types of food may be contaminated by Group A Streptococcus, including raw milk, ice cream, ham, potato salad, shrimps salad, steamed lobster via manipulation by ill handlers. Moreover, they may contaminate food with low content of free water, rich in salt or with very acidic $\mathrm{pH}$, which is generally difficult to be contaminated by other bacterial species.

Group A Streptococcus may cause several diseases, as bacteraemia, impetigo, erysipelas, pneumonia, osteomyelitis, septic arthritis, meningitis and toxic shock syndrome.

Among complications, acute rheumatic fever may follow respiratory infections as an autoimmune disease, in which antibodies raised against the streptococcal M-protein crossreact with autoantigens of pericardium and synovium.

Enterococci can cause food intoxication through production of biogenic amines, such as histamine and tyramine, mainly by the decarboxylation of amino acids in fish, meat and dairy products, wine, beer, vegetables, fruits, and nuts.

The genus Enterococcus is responsible for severe diseases, such as urinary tract infections, bacteraemia, bacterial endocarditis, diverticulitis, and meningitis.

\section{Vibrio cholerae}

Gram negative, slightly curved rod-shaped bacterium, which lives naturally in brackish waters, but can easily spread also in freshwater.

It can contaminate fish and seafood.

It is the aetiological agent of cholera, a serious illness that stroke Europe and North America during the XIX century with different outbreaks. Symptoms are nausea, vomiting, abdominal pain, watery diarrhoea which may induce severe dehydratation, that can be fatal if untreated.

Nowadays, cholera is endemic in India and rarely it causes outbreaks in Western countries. In 1991-1994, Latin America had an epidemic, in consequence of importation of contaminated seafood from Asia, with more than one million cases and 9600 deaths. In 2010, a new outbreak in Haiti has occurred.

\section{Vibrio parahaemolyticus}

Gram negative, slightly curved rod-shaped bacterium, which lives naturally in salt waters.

The related gastroenteritis follows the consumption of contaminated seafood. Symptoms include abdominal pain, vomiting, a burning sensation in the stomach and cholera-like watery faeces. Remission occurs within few days.

\section{Vibrio vulnificus}

As $V$. parahemolyticus, it is found in estuarine waters and contaminates seafood. It represents a serious threat for people with compromised immune system. In people with liver disease, it may cause septicaemia, with mortality rates often exceeding $50 \%$.

\section{Yersinia enterocolitica and Y. pseudotuberculosis}

Psycrofile Gram-negative bacteria which usually colonise the bowel of domestic animals and are transmitted by milk and meat. Outside their natural habitat, they are able to grow at refrigeration temperature $\left(4^{\circ} \mathrm{C}\right)$. The symptoms are diarrhoea, fever, headache and abdominal pain. 
For the most of the above described foodborne bacteria, the VBNC state has been proven by several studies. Therefore, the meaning of VBNC state as well as inducing and resuscitating factors have to be well understood, in order to plan how to face the difficulties of detection and make traceability feasible.

\section{The bacterial stress response}

In their natural environments, bacteria undergo fluctuating chemo-physical conditions, such as nutrient availability, temperature, osmolarity, and $\mathrm{pH}$, which may interfere with their growth and survival. In such a situation, they modulate their gene expression, in order to survive, by activating the bacterial stress response, which consists in variations of cell morphology, dimensions, energetic levels, directly related to cell survival. The final effect is an increased global resistance of surviving cells against further stresses, such as exposure to antibiotics, hydrogen peroxide and high osmolarity (Matin, 1991; Nyström et al., 1992).

In such a situation, some genera of Gram positive bacteria, as Bacillus, Clostridium and few others, differentiate into endospore.

Endospore is a differentiated bacterial cell in which new structures, required for mechanical and physical resistance, are synthesised. In the endospore, metabolism has been abolished by a controlled process of dehydration. The lack of metabolism confers a global resistance extended for prolonged periods of time. When environmental conditions become favourable, endospore undergoes germination, a process by which the metabolic activity is restored and cell turns to vegetative life.

The most of Gram positive and all Gram negative bacteria are not able to generate endospores. However, they can trigger a stress response with a highly-complex network of molecular mechanisms.

Studies carried on bacterial stress response have started from bacterial physiology in natural oligotrophic environments (Kurath \& Morita, 1983; Morita, 1982).

Subsequent studies have focused on the underlying molecular mechanisms, especially regarding a specific chemophysical stress and single-nutrients starvation (Eberl et al, 1996; Matin, 1991; Nakashima et al., 1996; Rockabrand et al., 1995).

One aspect on which little is known is that, in natural environments, nutritional and chemophysical factors inducing bacterial stress response may change simultaneously, with one specific factor influencing another and being, in turn, influenced by a third one.

Therefore, several mechanisms of bacterial stress responses should be activated. Unfortunately, few data are available about bacterial response to simultaneously-acting multiple stresses.

\subsection{The bacterial stress response to chemophysical stress}

Bacterial responses to chemophysical stresses, such as cold- and heat-shock, hyperosmolarity and acid $\mathrm{pH}$, have been investigated.

\subsubsection{The cold shock response}

It has been observed that $E$. coli, when subjected to a temperature decrease, triggers the cold shock response, in which sets of proteins are synthesised, globally indicated as CIPs (Cold 
Induced Proteins), as transcription regulators, ribosomal proteins, elongation factors and $\beta$ subunit of RNA-polymerase (Berger et al., 1996; Jones \& Inouye, 1996; Nakashima et al., 1996), in order to allow mRNAs transcription and protein synthesis.

\subsubsection{The heat shock response}

When subjected to heat shock, bacteria have to counteract macromolecules denaturation, so the overexpression of chaperones is induced to stabilize cell macromolecules and to degrade denaturised polypeptides (Gage \& Neidhardt, 1993; Spence, 1990).

\subsubsection{The osmotic shock response}

Osmotic shock causes considerable shrinkage of the cytoplasmic volume. In this process, known as plasmolysis, intracellular water tends to migrate towards the external environment. As a consequence, the concentrations of all the intracellular metabolites increase and thus reduce the intracellular water activity $\left(\mathrm{w}_{\mathrm{a}}\right)$. Bacteria may react by increasing the concentrations of solutes that have no effects on cell processes. Such solutes, called compatible solutes, are potassium ions, some amino acids (such as glutamate, glutamine, proline, $\gamma$-aminobutyrate, alanine), the quaternary amines glycinebetaine and some sugars (sucrose, threalose). Their accumulation inside the cells allows the cytoplasmic $\mathrm{w}_{\mathrm{a}}$ to be restored, with maintaining of metabolism (Csonka, 1989).

\subsubsection{The acid shock response}

When a sudden drop in $\mathrm{pH}$ occurs, bacteria generally use proton pumps, which literally pump protons out of the cell to keep the cytoplasmic $\mathrm{pH}$. Another approach is to increase the concentration of alkaline compounds within the cell to counteract the acidification of the cytoplasm (Bore et al., 2007).

\subsection{The bacterial stress response to nutrient starvation}

Under nutrient starvation, variations at structural, metabolic and physiological levels are observed.

During carbon starvation, heterotrophic bacteria enter a quiescent state, with a decrease in ATP content and a general reduction in metabolic activity. Moreover, gram negative rod bacteria undergo a characteristic morphology transition to spherical shape. When an energetic source becomes newly available, carbon-starved bacteria rapidly resume their metabolic activities, simultaneously restoring the rod shape (Givskov et al., 1994).

On the other hand, under nitrogen or phosphate starvation, anabolism is strongly reduced and the cell undergoes an energetic surplus, which is dissipated by futile cycles reactions or accumulation of high-energy storage compounds, such as PHAs (Eberl et al., 1996).

\section{The viable but nonculturable (VBNC) state}

One of the most intriguing findings on stressed bacteria in natural environments was the socalled viable but nonculturable (VBNC) state (Xu et al., 1982).

The VBNC state is defined as a state of dormancy triggered by environmental harsh conditions, such as nutrient starvation (Cook \& Bolster, 2007), temperature (Besnard et al., 
2002), osmotic stress (Asakura et al., 2008), oxygen availability (Kana et al., 2008), several food preservatives (Quirós et al., 2009), heavy metals (Ghezzi \& Steck, 1999), exposure to white light (Gourmelon et al., 1994) and decontaminating processes, as pasteurization of milk (Gunasekera et al., 2002) and chlorination of wastewater (Oliver et al., 2005).

In such a state, bacteria lose the ability to grow on solid media and undergo reduction in size; moreover, several metabolic variations occur, such as reductions in nutrient transport across cytoplasmic membrane, respiration rates, and macromolecular synthesis (Oliver, 2000; Porter et al., 1995). Biosynthesis does not cease, in that starvation and cold shock proteins are synthesized (McGovern \& Oliver, 1995; Morton \& Oliver, 1994). ATP levels remain high in VBNC cells (Beumer et al., 1992; Federighi et al., 1998). Further, recent studies have demonstrated continued gene expression by cells in the VBNC state (Lleò et al., 2000, 2001; Yaron and Matthews, 2002). Other cellular characteristics, such as cell wall (Signoretto et al., 2000; Signoretto et al., 2002) and membrane composition (Day and Oliver, 2004), differ remarkably from culturable cells.

When environmental conditions become permissive, resuscitation of VBNC bacteria occurs. Resuscitated bacteria are culturable on solid media and display the vegetative lifecycle.

Also resuscitation is a very complex phenomenon. A group of extracellular proteins, indicated as resuscitation promoting factors (Rpfs), play a key role in several other bacterial species (Hett et al., 2007; Mukamolova et al., 1998a, 1998b; Shleeva et al., 2004).

Another class of resuscitation factors is a heat-stable autoinducer of growth (Reissbrodt et al., 2002), which has been identified as a novel quorum-sensing system, termed AI-3 (Sperandio et al., 2003) and secreted after incubation in media containing norepinephrine (Freestone et al., 1999). Norepinephrine is produced in large amounts in humans following severe tissue injury, and is thus considered to be a stress-related hormone. Both epinephrine and norepinephrine could replace AI-3 in activating enterohaemorrhagic E. coli virulence gene expression (Sperandio et al., 2003).

These findings would support the hypothesis of resuscitation of VBNC enteropathogens in the human intestinal tract, at a time (e.g. tissue damage) when the host may be under significant physiological stress, with consequent secretion of norepinephrine.

Interestingly, even several higher organisms may induce resuscitation from the VBNC state.

Many conditions have been found to allow resuscitation of pathogens, as inoculation into yolk sacs of embryonated eggs (Cappelier et al., 1999b, 2007), into mice (Cappelier et al., 1999a) and into human volunteers (Colwell et al., 1996).

The observations of the VBNC state for the most of foodborne pathogens have raised several questions about the retention of virulence in such a state as well as recovery of virulence together with resuscitation in the host. The matter is highly debated because contrasting results have been presented. In some cases, virulence of L. monocytogenes in the VBNC state has been shown to depend on the experimental conditions adopted for resuscitation (Cappelier et al., 2005, 2007). It seems that VBNC pathogens are not generally able to initiate disease, but virulence is retained and infection can be initiated following their resuscitation. In fact, VBNC cells of Vibrio harveyi were avirulent, but resuscitated cells were lethal, indicating that VBNC $V$. harveyi cells retained pathogenic potential (Sun et al., 2008). Similarly, Oliver \& Bockian (1995) reported V. vulnificus to lose virulence for mice in 
proportion to the length of time that the cells were in the VBNC state. The cells retained virulence, however, and even when fully nonculturable, were able to cause fatal infections, with resuscitation occurring within the mouse. Continued virulence for a variety of pathogenic vibrios has also been demonstrated (Baffone et al., 2003).

Then, it can be concluded that VBNC forms of foodborne pathogen bacteria into a human or animal host may be a realistic threat for public health, because it has been demonstrated that virulence can be maintained or recovered after resuscitation.

\section{Role of food in induction of VBNC state}

Chemophysical characteristics of food select the bacteria able to colonize and survive.

Such characteristics, defined as intrinsic factors, are $\mathrm{pH}$, redox potential (or oxygen concentration) and $\mathrm{a}_{\mathrm{w}}$. However, other factors, that have to be considered, will be also discussed.

\section{$7.1 \mathrm{pH}$}

Although optimal bacterial growth requires a $\mathrm{pH}$ near neutrality, it has been demonstrated that foodborne pathogens can trigger the acid shock response for survival in acidic environments.

Then, acidic food may be an environment inducing the VBNC state and risk becomes higher for food, as fresh juices and salads, not subjected to antimicrobial treatments.

\subsection{Redox potential (or oxygen concentration)}

Food redox potential is a factor which influences the development of bacteria. Vegetable food has a redox potential ranging from +300 and $-400 \mathrm{mV}$, which favours aerobes and eukaryotic microrganisms (yeasts and moulds). Meat has a value of $-200 \mathrm{mV}$, which allows persistence of microaerobes and anaerobes bacteria.

Oxygen influences food redox potential, so its concentration is critical for bacterial growth. Aerobe bacteria need oxygen for growth, whereas anaerobes use compounds other than oxygen, such as nitrate, nitrite, sulphate, sulphite, etc. Some anaerobes, defined obligate, have been considered as totally inhibited by presence of oxygen for a long time, in that were believed to be unable to face the oxidative damage caused by Reactive Oxygen Species (ROS). Nowadays, it has been demonstrated that Clostridium may withstand oxidative stress, in that genome sequencing revealed the presence of genes related to oxygen metabolism (Kawasaki et al., 2005).

Also oxidative stress may induce VBNC state, as demonstrated in Vibrio sp. (McDougald \& Kjelleberg, 2006).

\subsection{Water activity $\left(\mathrm{a}_{\mathrm{w}}\right)$}

The $a_{w}$ is a measure of free water available for microbial growth and its value ranges from 1.00 of mineral water to 0.60 of bakery products, candies and dried fruit. A range of $\mathrm{a}_{\mathrm{w}}$ around 0.995 to 0.998 allows the growth of most of bacteria. The use of salting as ancient 
conservation technique for meat and vegetables consists, ultimately, in bringing down $\mathrm{a}_{\mathrm{w}}$ to reduce microbial development.

As already stated, bacteria may face osmotic shock; moreover, high osmolarity may induce VBNC state (Asakura et al., 2008).

\subsection{Chemical composition}

Biological macromolecules are used as substrates for growth, but bacteria may use only a limited part of the macromolecular content. Moreover, several compounds, such as polyphenols of fruit and vegetables and organic acids, display bacteriostatic and bactericide activities, which are further stress-inducing factors.

\subsection{Feedstock treatment}

Decontamination procedures, such as pasteurisation, salting and acidification, can induce VBNC state (Gunasekera et al., 2002; Makino et al., 2000; Quirós et al., 2009). Moreover, untreated food is more susceptible to microbial contamination (Erickson et al., 2010).

\subsection{Food storage}

Before consumption, food is stored during packaging, distribution and commercialization. Time and temperature are critical factors which are related to bacterial stress response and induction of VBNC state (Besnard et al., 2002).

\subsection{Presence of endogenous microflora}

Feedstock and untreated food possess a resident microflora, not necessarily hazardous for human health. Such microflora may interact with contaminating bacterial pathogens by intercellular exchange of signalling molecules, as the autoinducers, which may activate secretion of virulence factors or resuscitation in VBNC bacteria (Reissbrodt et al., 2002).

\section{VBNC state of foodborne bacteria - The new challenge in food safety}

Despite the few studies, strong evidences of VBNC bacteria in food have been reported. In stored wine, for example, acetic acid and lactic acid bacteria entered VBNC state as consequence of lack of oxygen and presence of sulphites, respectively (Millet and LonvaudFunel, 2000).

The role played by chemo-physical characteristics of food in triggering VBNC state in foodborne pathogen bacteria is poorly undestood. The most of the studies consists in analysing the effects provoked by a single stress on a homogeneous population of bacteria.

However, it has to be considered that, in their habitat, bacteria are continuously subjected to the simultaneous action of factors, as nutrient availability, $\mathrm{pH}$, osmolarity, temperature, presence of toxic compounds, ecological competition with other organisms, which are continuously changing. The time and the entity of the change of a single factor influences, and in turn is influenced by, changes and entities of other factors, according to chaos dynamics observed in nature, in an unpredictable way. 
In the same way, food and its surrounding environment have to be considered as a complex system, in which the chemo-physical characteristics ( $\mathrm{pH}, \mathrm{a}_{\mathrm{w}}$, chemical composition) and environmental factors (storage temperature and time, decontamination treatments, packaging under modified atmosphere) act simultaneously on contaminating bacteria.

It has been demonstrated (Nicolò et al., 2011) that refrigerated pasteurised grapefruit juice induces VBNC state in E. coli O157:H7 and S. Typhimurium within 24 hours of incubation.

Grapefruit has a very acidic $\mathrm{pH}$, low content in carbohydrates and several antimicrobial compounds. Such characteristics, generally described as factors inducing VBNC state in laboratory, together with the refrigeration used for storage, suggested the hypothesis that grapefruit juice could induce VBNC state in foodborne pathogens.

On the contrary, grape juice, which differs from grapefruit juice for the higher content in carbohydrates, did not induce VBNC state (Nicolò et al., unpublished data), despite the acidic $\mathrm{pH}$ and refrigeration temperature.

Therefore, the role of food in induction of VBNC state has to be elucidated. Predictive models offered by biomathematics and bioinformatics would be very helpful tools, in order to evaluate the possibility that, under certain conditions, pathogen bacteria contaminating a tipology of food may enter the VBNC state.

In pasteurised milk, de novo expression of a $g f p$ reporter gene has been demonstrated to be higher than culturable cells for both E. coli and Pseudomonas putida, so showing that, after thermal treatment, contaminant bacteria had lost the ability to form colonies, but retained transcription and translation machineries (Gunasekera et al., 2002).

A study on dried salted squid contaminated by Salmonella enterica subsp. enterica Oranienburg, responsible for an outbreak in Japan in 1999, has showed the inefficacy of cultural methods for detection of VBNC bacteria. In such a study, less than 20 culturable cells were recovered by plating a sample of salted squid, a value that cannot support the septicaemia observed in patients, but BacLight assay showed that more than $90 \%$ of the population was viable. In such a way, the hypothesis that an outbreak of foodborne bacteria in VBNC state could be underestimated on the basis of culturable cells has been demonstrated (Asakura et al., 2002).

In another outbreak in Japan, due to contamination of salted salmon roe by E. coli $\mathrm{O} 157$ in VBNC state, the authors demonstrated the resuscitation in vivo of VBNC bacteria and the maintaining of virulence in mice (Makino et al., 2000).

Such studies demonstrate that also treatments for food preservation have to be considered as a possible factor inducing pathogen bacteria into VBNC state. On the basis of such observations, the role of preservation treatments has to be investigated, in order to identify the critical points of a given procedure and make the adequate corrections.

\section{Detection of VBNC bacteria}

Actually, several systems for VBNC detection in water environments have been set up. Such systems are based on fluorescent staining, DNA hybridization and mRNA quantization.

Many fluorescent stains are used as indicators of metabolic activity (or viability), because they can accept the electrons flowing through cell respiratory chains. The most common are 
known as tetrazolium salts, as 5-cyano-2,3-ditolyl tetrazolium chloride (CTC) and 2-(4iodophenyl)-3-(4-nitrophenyl)-5-phenyl tetrazolium chloride (INT).

In recent years, a new differential staining assay, the BacLight ${ }^{\circledR}$ Live/Dead assay, has been developed. The assay allows to simultaneously count total and viable (metabolically active) cells, by using two nucleic acid stains, that is green-fluorescent SYTO ${ }^{\circledR} 9$ stain and redfluorescent propidium iodide stain. These stains differ in their ability to penetrate intact cell membranes. When used alone, SYTO ${ }^{\circledR} 9$ stain labels both live and dead bacteria. In contrast, propidium iodide penetrates only bacteria with damaged membranes, reducing SYTO ${ }^{\circledR} 9$ fluorescence when both dyes are present. Thus, live bacteria with intact membranes fluoresce green, while dead bacteria with damaged membranes fluoresce red.

CTC, INT and BacLight ${ }^{\circledR}$ Live/Dead assay are commonly used for the Direct Viable Count (DVC), by visualization of VBNC bacteria under fluorescence microscopy, one of the most widespread techniques for assessing bacterial viability (Rowan, 2011).

When DVC values are higher than culturable cells, obtained by CFU assay (that is when cell viability is higher than culturability), then it is assumed that bacteria have entered VBNC state.

Fluorescent antibodies have also been employed in DVC for VBNC detection of E. coli in recreational water (Zimmerman et al., 2009). In such technique, the sample is incubated in presence of yeast extract and nalidixic acid, which inhibits bacterial replication. Then, living cells increase their biomass, but cannot duplicate, so they elongate or enlarge. After addition of fluorescent antibody, fluorescing cells with altered morphology can be counted with epifluorescence microscopy. The difference between fluorescing cells, obtained by DVC, and culturable cells, obtained by CFU assay, indicates the presence of VBNC bacteria.

DNA hybridization is based on the identification of nucleic acid sequences that are specific for a given species, such as those present in ribosomes (16S and $23 \mathrm{~S}$ rRNAs), by using a fluorescent known DNA sequence, called probe.

In fluorescence in situ hybridization (FISH), the hybridization between probe and nucleic acid sequence can be visualized in epifluorescence microscopy and used for DVC after incubation of the sample in a medium containing an antibiotic which prevents bacterial division. Comparison between DVC and culture count by miniaturized most-probable number (MPN) gives information about the presence of VBNC cells (Garcia-Armisen, 2004; Servais et al., 2009).

Flow cytometry has been successfully employed to gather information about cell viability, antigenic surface components, and the quantification of morphological variations of $V$. parahaemolyticus during entry into the VBNC state (Falcioni et al., 2008).

mRNA quantization is performed by quantitative reverse transcription polymerase chain reaction (qRT-PCR). Such technique is derived from the classic polymerase chain reaction (PCR), which allows the synthesis of huge quantities of a DNA sequence.

Dunaev et al. (2008) recently reported on the rapid and accurate quantification of VBNC pathogens in biosolids via monitoring and quantifying stress-related genes in Salmonella spp. using cDNA microarrays combined with qRT-PCR. Quantification of mRNA was correlated to cell viability and their ability to grow. 
Other techniques, such as microradiography, have been proposed for VBNC identification, but they resulted to be time-consuming and quite expensive.

The above described detection methods, used in water environment, are not part of routinary food safety procedures, in that they are not simple enough, the equipment is too expensive and specialised technical personnel is necessary.

Moreover, it has to be considered that food could be quite difficult to investigate, because of the presence of heterogeneous compounds that could interfere with the molecular reaction required by a single detection technique.

However, new methods for VBNC detection should be designed, in terms of rapidity, sensitivity and ease of use.

\section{Social and economical consequences of an outbreak}

In any outbreak, beyond the health aspect, several social and economic implications are strictly associated to the emergence of a foodborne disease.

$20 \%$ of illnesses are referable to known pathogens, but the remaining $80 \%$ is due to unspecified agents, intended as known agents not yet identified as cause of foodborne illness, agents known to be in food whose pathogenicity is not proven and unidentified agents.

As consequence, their traceability by traditional food safety methods is difficult.

In this regard, VBNC role in foodborne outbreaks has still to be defined.

In fact, the appearance of an outbreak has a critical effect on public opinion, generating fears that often become panic. The difficulty of a correct communication among health authorities, politics and people has been matter of study by World Health Organization, which published a manual containing the guidelines to overcome such problem.

Moreover, the difficulty to identify in a timely fashion the primary causes of the outbreak has a negative impact at economic level, because any foodstuff suspected to be infected is removed from the market and destroyed, with consequent economic losses.

The management of the recent outbreak of E. coli O104:H4 in Germany can be considered as a good source for several considerations.

At the onset of the outbreak, the identification of the aetiological agent was erroneous and only later it was demonstrated that the true cause was an enteroaggregative E. coli strain, able to synthesize Shiga toxins.

The source of infection was sprouted food produced by an organic farm in Bienenbüttel, Lower Saxony, Germany; local laboratories failed in finding the pathogen and correct identification was achieved later by a laboratory in North Rine-Westphalia.

Before the test results, German health authorities erroneously declared that the pathogen was present in cucumbers imported from Spain. Later, they admitted that the E. coli strain responsible of the outbreak was not found in cucumber samples they had analysed. 
As consequence of the false information, Spanish exporters lost more than 200 millions of Euro per week. Political tension between Spain and Germany exploded on behalf of the European summit in Debrecen, Hungary, where the Spanish Minister of Agriculture publicly accused the German government of irresponsible behaviour. Spain, in fact, is the first world producer of cucumbers and more than $90 \%$ of its agricultural produce is exported in Europe. The destruction of vegetables and fruit had dramatic economic losses, because at that time Spain was already heavily hit by international financial crisis.

Moreover, Russia banned the import of fresh vegetable from Europe, with economic consequences which impacted on all the countries of European Union.

Another cause of diplomatic tension was a joint risk-assessment by European Food Safety Agency (EFSA)/European Centre for Disease Prevention and Control (ECDC), which identified a link between the German outbreak and a simultaneous haemolytic urea syndrome outbreak in France, caused by the same E. coli strain. The assessment indicated fenugreek seeds imported in Europe from Egypt as a possible source of contamination, even if in the same document it was stated that such hypothesis had to be truly demonstrated. Such behaviour induced the Egyptian Minister of Agriculture to comment such opinions as "sheer lies".

Several critical points about the German outbreak management emerge. First of all, standard procedures for the fast and unambiguous pathogen(s) identification are required, in order to alert health care points and allow them to plan the best response for people assistance.

Then, a real-time communication between health care points and national health authorities is needed, for continuous monitoring of the outbreak.

Health authorities have to communicate with politics, to plan the best way to inform people about the situation, giving appropriate information and warnings.

Further, communication among health authorities of the countries involved in the outbreak has to be promoted, to efficiently identify the causes of the outbreak and track it.

Communication, then, is the keystone for the best management of an outbreak. Appropriate procedures have to be established, with the creation of multilevel joint committees, formed by health and political authorities, which have to control quality and completeness of available information and manage subsequent communication to public opinion.

The importance of communication has been matter of the WHO Expert Consultation on Outbreak Communications held in Singapore on 2004. As result, a manual containing the guidelines to be followed has been published and is freely available (WHO, 2005).

\section{International programs devoted to monitoring and tracking of foodborne pathogens}

Surveillance of foodborne disease is a fundamental component of food safety systems and data are used for planning, implementing and evaluating public health policies. There is therefore a strong need to strengthen such systems, particularly for establishing whether VBNC foodborne pathogens may be responsible for an outbreak. 
In this regard, the New Zealand Food Safety Authority has charged the Institute of Environmental Science and Research Limited to investigate the resuscitation of putative VBNC foodborne bacteria of significance to New Zealand. The final report concluded that some foodborne pathogen bacteria may become VBNC under certain conditions, that there may be no universal system for resuscitation of VBNC cells and that the phenomenon may be highly variable and bacterial species specific.

The difficulty in investigating the VBNC state and the related potential risk did not allow health authorities to establish guidelines for their detection.

Anyway, several efforts are carried out for surveillance of emerging foodborne diseases, creating new and interdisciplinary teams of research for data generation, collection and analysis.

In 2000, the Food and Agriculture Organization (FAO) of the United Nations and World Health Organization (WHO) started to expand their activities in the area of microbiological risk assessment to meet the increasing need for risk-based scientific advice and information and tools to undertake microbiological risk assessment. FAO and WHO coordinate their work in this area through the implementation of joint FAO/WHO meetings on microbiological risk assessment (JEMRA).

The activities of JEMRA can be categorised as follows:

- Generation of scientific information - risk assessments

- Elaboration of guideline documents

- Data collection and generation

- Use of risk assessment within a risk management framework

- Information and technology transfer

Moreover, $\mathrm{WHO}$ is promoting many programs and projects, by the creation of several worldwide collaborations involving technical existing structures, to give support, information and instructions on how to face an incoming outbreak.

The Global Alert and Response (GAR) is an integrated system for epidemics and other public health emergencies based on strong national public health systems and capacity and an effective international system for coordinated response.

The Global Outbreak Alert and Response Network (GOARN) is a technical collaboration of existing institutions and networks that pool human and technical resources for the rapid identification, confirmation and response to outbreaks of international importance. The Network provides an operational framework to link this expertise and skill to keep the international community constantly alert to the threat of outbreaks and ready to respond.

In 2011, United States President Obama signed into law the FDA Food Safety Modernization Act (FSMA). It aims to ensure the U.S. food supply is safe by shifting the focus of federal regulators from responding to contamination to preventing it. As a mandate, the FDA will launch a test of two different programs that they hope will help with locating the source of food contamination more quickly. 
One program will track processed foods, and the other will trace raw fruits and vegetables. The program will focus on keeping more detailed records of food and the path it makes as it travels across the country.

A new project has been established at Centers for Disease Control and Prevention (CDC), in collaboration with the Food and Drug Administration (FDA), which is called the Foodborne Disease Active Surveillance Network or FoodNet.

The project consists of active surveillance for foodborne diseases and related epidemiologic studies designed to help public health officials better understand the epidemiology of foodborne diseases in the United States.

In the United States, using FoodNet data from 2000-2007, the Centers for Disease Control and Prevention estimated that 48 million people get sick, 127,839 were hospitalized and 3,037 people died.

Similarly, the European Food Safety Authority (EFSA) is the keystone of European Union (EU) risk assessment regarding food and feed safety and emerging risks, in close collaboration with national authorities.

Particularly, European food safety policy is to ensure a high level of protection of human health and consumers' interests in relation to food, taking into account diversity, including traditional products, whilst ensuring the effective functioning of the internal market.

Since 2000, the European Commission's guiding principle, primarily set out in its White Paper on Food Safety, is to apply an integrated approach from farm to table covering all sectors of the food chain, from feed production to transport and retail sale.

Moreover, the regional office for Europe of WHO supports countries in building capacity to manage food safety challenges in accordance with the WHO European Action Plan for Food and Nutrition Policy 2007-2012 and the WHO global strategy for food safety. The Action Plan is an important guide for policy-makers and health professionals that includes a wide range of actions in the area of food safety.

Despite the care by public health entities to track efficiently many known foodborne pathogens and identify the possibility of outbreaks, it is known that a consistent number of outbreaks is due to unknown pathogens. Such data may be due to microbes that are not proven to cause diseases as well as to VBNC state of known foodborne pathogen bacteria that, up to date, are undetectable.

\section{Conclusions}

Foodborne pathogens are the greatest threat to food safety. Despite the several efforts, much remains to be done to reach the national health objectives.

The first action to be taken is the enhancement of measures to reduce or prevent contamination in the food and to educate stakeholders more effectively about risks and prevention measures.

Whereas in developed countries food safety procedures and surveillance network monitor continuously the insurgence of possible emergencies, the situation is drastically different in developing countries, where many difficulties have to be considered. 
In general, the lack of people education is the first problem, in that social habits as well as cultural factors may favour the spread of a foodborne infection.

Then, people education is the keystone needed to strongly limit the raise and diffusion of an outbreak within a community.

Moreover, a continuous support, in terms of updating of political authorities and retraining of health personnel, could contribute to an efficient action by the local governments.

Another step for developing countries is the creation of a permanent educational system that allows people, since infancy to adult age, to be informed about foodborne infections, their causes and ways of spreading. In this way, such information will become part of the community culture and will be transmitted to the future generations.

Overall, it is important to encourage the local formation of specialised personnel in healthcare sector for medical care, research, monitoring and communication.

Furthermore, it would be also desirable that international health authorities could take into account the focusing of VBNC state of foodborne bacteria. In fact, despite the studies performed up to date, several topics have to be clarified, that is $i$ ) the risk that food may induce VBNC state in contaminating foodborne pathogens; ii) wheter VBNC state can be considered as a resistance strategy against stress or a transitory condition which precedes cell death; iii) the factors triggering the VBNC state; iv) the factors triggering the resuscitation and $v$ ) the maintaining of the virulence.

In fact, in food field it is very important to fit into a global frame the effects of the various food parameters, as chemophysical characteristics, decontamination procedures and storage conditions and time. All these factors, in fact, may be source of multiple and subsequent stresses for contaminating pathogen bacteria and evaluating the possibility of onset of VBNC state is a primary need. In such sense, bioinformatics and predictive mathematical models could be a powerful tool to identify whether a specific association of different stresses acting on a bacterial population may induce the entry into VBNC state.

Unfortunately, up to date detection of VBNC foodborne pathogen bacteria in food is problematic.

New methods have been proposed for VBNC detection, but they are not satisfying in that difficult to use as routinary procedures.

Therefore, innovative detection procedures, in terms of ease of use and rapidity of analysis, are urgently needed to allow an efficient monitoring and tracking of foodborne VBNC to prevent outbreaks in today's and future global market.

\section{References}

Asakura, H., Makino, S.I., Takagi, T., Kuri, A., Kurazano, T., Watarai M. \& Shirahata, T. (2002). Passage in Mice Causes a Change in the Ability of Salmonella enterica Serovar Oranienburg to Survive $\mathrm{NaCl}$ Osmotic Stress: Resuscitation from the Viable but Non-culturable State. FEMS Microbiology Letters, Vol.212, No.1, (June 2002), pp. 8793, ISSN 0378-1097 
Asakura, H., Kawamoto, K., Haishima, Y., Igimi, S., Yamamoto, S. \& Makino, S.I. (2008). Differential Expression of the Outer Membrane Protein W (OmpW) Stress Response in Enterohaemorrhagic Escherichia coli O157:H7 Corresponds to the Viable but Non-culturable State. Research in Microbiology, Vol.159, No.9-10, (November-December 2008), pp. 709-717, ISSN 0923-2508

Baffone, W., Citterio, B., Vittoria, E., Casaroli, A., Campana, R., Falzano, L. \& Donelli, G. (2003). Retention of Virulence in Viable but Nonculturable Halophilic Vibrio spp. International Journal of Food Microbiology, Vol.89, No.1, (December 2003), pp. 31-39, ISSN 0168-1605

Berger, F., Morellet, N., Menu, F. and Potier, P. (1996). Cold Shock and Cold Acclimation Proteins in the Psychrotrophic Bacterium Arthrobacter globiformis SI55. Journal of Bacteriology, Vol.178, No.11, (June 1996), pp. 2999-3007, ISSN 0021-9193

Besnard, V., Federighi, M., Declerq, E., Jugiau, F. \& Cappelier, J.M. (2002). Environmental and Physico-chemical Factors Induce VBNC State in Listeria monocytogenes. Veterinary Research, Vol.33, No.4, (July-August 2002), pp. 359-370, ISSN 0928-4249

Beumer, R.R., de Vries, J. \& Rombouts, F.M. (1992). Campylobacter jejuni Non-culturable Coccoid Cells. International Journal of Food Microbiology, Vol.15, No.1-2, (JanuaryFebruary 1992), pp. 153-163, ISSN 0168-1605

Bore, E., Langsrud, S., Langsrud, Ø., Rode, T.M. \& Holck, A. (2007). Acid-shock Responses in Staphylococcus aureus Investigated by Global Gene Expression Analysis. Microbiology, Vol.153, No.7, (July 2007), pp. 2289-2303, ISSN 1350-0872

Cappelier, J.M., Magras, C., Jouve, J.L. \& Federighi, M. (1999a). Recovery of Viable but Nonculturable Campylobacter jejuni Cells in Two Animal Models. Food Microbiology, Vol.16, No.4, (August 1999), pp. 375-383, ISSN 0740-0020

Cappelier, J.M., Minet, J., Magras, C., Colwell, R.R. \& Federichi, M. (1999b). Recovery in Embryonated Eggs of Viable but Nonculturable Campylobacter jejuni Cells and Maintenance of Ability to Adhere to HeLa Cells after Resuscitation. Applied and Environmental Microbiology, Vol.65, No.11, (November 1999), pp. 5154-5157, ISSN 0099-2240

Cappelier, J.M., Besnard, V., Roche, S., Garrec, N., Zundel, E., Velge, P. \& Federighi, M. (2005). Avirulence of Viable but Non-culturable Listeria monocytogenes Cells Demonstrated by in Vitro and in Vivo Models. Veterinary Research, Vol.36, No.4, pp. 589-599, (July-August 2005), ISSN 0928-4249

Cappelier, J.M., Besnard, V., Roche, S.M., Velge, P. \& Federighi, M. (2007). Avirulent Viable but Non-culturable Cells of Listeria monocytogenes Need the Presence of an Embryo to be Recovered in Egg Yolk and Regain Virulence after Recovery. Veterinary Research, Vol.38, No.4, (July-August 2007), pp. 573-583, ISSN 0928-4249

Colwell, R.R., Brayton, P.R., Herrington, D., Tall, B.D., Huq, A. \& Levine M.M. (1996). Viable but Nonculturable Vibrio cholerae O1 Revert to a Culturable State in Human Intestine. World Journal of Microbiology and Biotechnology, Vol.12, No.1, (January 1996), pp. 28-31, ISSN 0959-3993

Cook, K.L. \& Bolster, C.H. (2007). Survival of Campylobacter jejuni and Escherichia coli in Groundwater During Prolonged Starvation at Low Temperatures. Journal of Applied Microbiology, Vol.103, No.3, (September 2007), pp. 573-583, ISSN 1364-5072

Csonka, L.N. (1989). Physiological and Genetic Responses of Bacteria to Osmotic Stress. Microbiological Reviews, Vol.53, No.1, (March 1989), pp. 121-147, ISSN 0146-0749 
Day, A.P. \& Oliver, J.D. (2004). Changes in Membrane Fatty Acid Composition during Entry of Vibrio vulnificus into the Viable but Nonculturable State. The Journal of Microbiology, Vol.42, No.2, (June 2004), pp. 69-73, ISSN 1225-8873

Dunaev, T., Alanya, S. \& Duran, M. (2008). Use of RNA-based Genotypic Approaches for Quantification of Viable but Nonculturable Salmonella sp. in Biosolids. Water Science and Technology, Vol.58, No.9, (n.d.), pp. 1823-1828, ISSN 0273-1223

Eberl, L., Givskov, M., Sternberg, C., Møller, S., Christiansen, G. \& Molin, S. (1996). Physiological Responses of Pseudomonas putida KT2442 to Phosphate Starvation. Microbiology, Vol.142, No.1, (January 1996), pp. 155-163, ISSN 1350-0872.

Erickson, M.C., Webb, C.C., Diaz-Perez, J.C., Phatak, S.C., Silvoy, J.J., Davey, L., Payton, A.S., Liao, J., Ma, L. \& Doyle M.P. (2010). Surface and Internalized Escherichia coli O157:H7 on Field-Grown Spinach and Lettuce Treated with Spray-Contaminated Irrigation Water. Journal of Food Protection, Vol.73, No.6, (June 2010), pp. 1023-1029, ISSN 0362-028X

Falcioni, T., Papa, S., Campana, R., Manti, A., Battistelli, M. \& Baffone, W. (2008). State Transitions of Vibrio parahaemolyticus VBNC Cells Evaluated by Flow Cytometry. Cytometry Part B (Clinical Cytometry), Vol.74, No.5, (September 2008), pp. 272-281, ISSN 1552-4949

Federighi, M., Tholozan, J.L., Cappelier, J.M., Tissier, J.P. \& Jouve, J.L. (1998). Evidence of Non-coccoid Viable but Non-culturable Campylobacter jejuni Cells in Microcosm Water by Direct Viable Count, CTC-DAPI Double Staining, and Scanning Electron Microscopy. Food Microbiology, Vol.15, No.5, (October 1998), pp. 539-550, ISSN 07400020

Freestone, P.P.E., Haigh, R.D., Williams, P.H. \& Lyte, M. (1999). Stimulation of Bacterial Growth by Heat-stable, Norepinephrine-induced Autoinducers. FEMS Microbiology Letters, Vol.172, No.1, (March 1999), pp. 53-60, ISSN 0378-1097

Gage, J. \& Neidhardt, F.C. (1993). Modulation of the Heat Shock Response by One-carbon Metabolism in Escherichia coli. Journal of Bacteriology, Vol.175, No.7, (April 1993), pp. 1961-1970 ISSN 0021-9193

Garcia-Armisen, T. \& Servais, P. (2004). Combining Direct Viable Counts (DVC) and Fluorescent in Situ Hybridization (FISH) to Enumerate Viable Escherichia coli in Rivers and Wastewaters. Water Science and Technology, Vol.50, No.1, (n.d.), pp. 271275, ISSN 0273-1223

Ghezzi, J.I. \& Steck, T.R. (1999). Induction of the Viable but Nonculturable Conditions in Xanthomonas campestris pv. campestris in Liquid Microcosms and Sterile Soil. FEMS Microbiology Ecology, Vol.30, No.3, (November 1999), pp. 203-208, ISSN 0168-6496

Givskov, M., Eberl, L., Møller, S., Poulsen, L.K., Molin, S. (1994). Responses to Nutrient Starvation in Pseudomonas putida KT2442: Analisys of General Cross-protection, Cell Shape, and Macromolecular Content. Journal of Bacteriology,. 1994 Vol.176, No.1, (January 1994), pp. 7-14, ISSN 0021-9193

Gourmelon, M., Cillard, J. \& Pommepuy, M. (1994) Visible Light Damage to Escherichia coli in Seawater: Oxidative Stress Hypothesis. Journal of Applied Microbiology, Vol.77, No.1, (July 1994), pp. 105-112, ISSN 1364-5072

Gunasekera, T.S., Sørensen, A., Attfield, P.V., Sørensen, S.J. \& Veal, D.A. (2002). Inducible Gene Expression by Nonculturable Bacteria in Milk after Pasteurization. Applied 
and Environmental Microbiology, Vol.68, No.4, (April 2002), pp. 1988-1993, ISSN 0099-2240

Hett, E.C., Chao, M.C., Steyn, A.J., Fortune, S.M., Deng, L.L. \& Rubin, E.J. (2007). A Partner for the Resuscitation-promoting Factors of Mycobacterium tuberculosis. Molecular Microbiology, Vol.66, No.3, (November 2007), pp. 658-668, ISSN 0950-382X

Jones, P.G. \& Inouye, M. (1996). RbfA, a 30 S Ribosomal Binding Factor, is a Cold-Shock Protein Whose Absence Triggers the Cold-Shock Response. Molecular Microbiology, Vol.21, No.6, (September 1996), pp. 1207-1218, ISSN 0950-382X

Kana, B.D., Gordhan, B.G., Downing, K.J., Sung, N., Vostroktunova, G., Machowski, E.E., Tsenova, L., Young, M., Kaprelyants, A., Kaplan, G. \& Mizrahi, V.1. (2008). The Resuscitation-promoting Factors of Mycobacterium tuberculosis are Required for Virulence and Resuscitation from Dormancy but are Collectively Dispensable for Growth in Vitro. Molecular Microbiology, Vol.67, No.3, (February 2008), pp. 672-684, ISSN 0950-382X

Kawasaki, S., Watamura, Y., Ono, M., Watanabe, T., Takeda, K. \& Niimura, Y. (2005). Adaptive Responses to Oxygen Stress in Obligatory Anaerobes Clostridium acetobutylicum and Clostridium aminovalericum. Applied and Environmental Microbiology, Vol.71, No.12, (December 2005), pp. 8442-8450, ISSN 0099-2240

Kelly, S.M., Pitcher, M.C.L., Farmery, S.M. \& Gibson, G.R. (1994). Isolation of Helicobacter pylori from Feces of Patients with Dyspepsia in the United Kingdom. Gastroenterology, Vol.107, No.6, (December 1994), pp. 1671-1674, ISSN 0016-5085

Kurath, G. \& Morita, R.Y. (1983). Starvation-Survival Physiological Studies of a Marine Pseudomonas sp. Applied and Environmental Microbiology, Vol.45, No.4, (April 1983), pp. 1206-1211, ISSN 0099-2240

Lleò, M.M., Pierobon, S., Tafi, M.C., Signoretto, C. \& Canepari, P. (2000). mRNA Detection by Reverse Transcription-PCR for Monitoring Viability over Time in an Enterococcus faecalis Viable but Nonculturable Population Maintained in a Laboratory Microcosm. Applied and Environmental Microbiology, Vol.66, No.10, (October 2000), pp. 4564-4567, ISSN 0099-2240

Lleò, M.M.; Bonato, B.; Tafi, M.C.; Signoretto, C.; Boaretti, M. \& Canepari, P. (2001). Resuscitation Rate in Different Enterococcal Species in the Viable but Nonculturable State. Journal of Applied Microbiology, Vol.91, No.6, (December 2001), pp. 1095-1102, ISSN 1364-5072,

Loftis, A.D.; Priestley, R.A. \& Massung, R.F. (2010). Detection of Coxiella burnetii in Commercially Available Raw Milk from the United States. Foodborne Pathogens and Disease, Vol.7, No.12, (December 2010), pp. 1453-1456, ISSN 1535-3141

Makino, S.I.; Kii, T.; Asakura, H.; Shirahata, T.; Ikeda, T.; Takeshi, K. \& Itoh, K. (2000). Does Enterohaemorrhagic Escherichia coli O157:H7 Enter the Viable but Nonculturable State in Salted Salmon Roe? Applied and Environmental Microbiology, Vol.66, No.12, (December 2001), pp. 5536-5539, ISSN 0099-2240

Matin, A. (1991). The Molecular Basis of Carbon-Starvation-Induced General Resistance in Escherichia coli. Molecular Microbiology, Vol.5, No.1, (January 1991), pp. 3-10, ISSN 0950-382X

McDougald, D. \& Kjelleberg, S. (2006). Adaptive Responses of Vibrios. In: The biology of vibrios, F. L Thompson,. B. Austin \& J. G. Swings (Eds.), 133-155, ASM Press, ISBN 1555813658, Herndon, Virginia, United States 
McGovern, V.P. \& Oliver, J.D. (1995). Induction of Cold Responsive Proteins in Vibrio vulnificus. Journal of Bacteriology, Vol.177, No.14, (July 1995), pp. 4131-4133, ISSN 0021-9193

Millet, V., \& Lonvaud-Funel, A. (2000). The viable but non-culturable state of wine microorganisms during storage. Letters in Applied Microbiology, Vol.30, No.2, (February 2000), pp.136-141, ISSN 0266-8254

Morita, R.Y. (1982). Starvation-Survival of Heterotophs in the Marine Environment. Advances in Microbial Ecology, Vol.6, (n.d.), pp. 117-198, ISSN 0147-4863

Morton, D. \& Oliver, J.D. (1994). Induction of Carbon Starvation Proteins in Vibrio vulnificus. Applied and Environmental Microbiology, Vol.60, No.10, (October 1994), pp. 36533659, ISSN 0099-2240

Mukamolova, G.V., Kaprelyants, A.S., Young D.I., Young, M. \& Kell, D.B. (1998a). A bacterial cytokine. Proceedings of National Academy of Sciences, Vol.95, No.15, (July 1998), pp. 8916-8921, ISSN 0027-8424

Mukamolova, G.V.; Yanopolskaya, N.D.; Kell, D.B. \& Kaprelyants, A.S. (1998b). On resuscitation from the dormant state of Micrococcus luteus. Antonie Van Leeuwenhoek, Vol.73, No.3, (Apr 1998), pp. 237-243, ISSN 0003-6012

Nakashima, K., Kanamaru, K., Mizuno, T. \& Horikoshi, K. (1996). A Novel Member of the cspA Family of Genes that is Induced by Cold Shock in Escherichia coli. Journal of Bacteriology, Vol.178, No.10, (May 1996), pp. 2994-2998, ISSN 0021-9193

Nesbakken, T. (2007). Pig Herds Free from Human Pathogenic Yersinia enterocolitica. Emerging Infectious Diseases, Vol.13, No.12, (December 2007), pp. 1860-1864, ISSN 1080-6059

Nicolò, M.S., Gioffre`, A., Carnazza, S., Platania, G., Di Silvestro, I. and Guglielmino, S.P.P. (2011) Viable but Nonculturable State of Foodborne Pathogens in Grapefruit Juice: a Study of Laboratory. Foodborne Pathogens and Disease, Vol.8, No.1, (January 2011), pp. 11-17, ISSN 1535-3141

Nyström, T., Olsson, R.M. \& Kjelleberg, S. (1992). Survival, Stress Resistance, and Alterations in Protein Expression in the Marine Vibrio sp. Strain S14 during Starvation for Different Individual Nutrients. Applied and Environmental Microbiology, Vol.58, No.1, (January 1992), pp. 55-65, ISSN 0099-2240

Oliver, J.D. (2000). Problems in Detecting Dormant (VBNC) Cells and the Role of DNA Elements in This Response, In: Tracking Genetically-engineered Microorganisms, J.K. Jansson, J.D. van Elsas, and M.J. Bailey (eds.), 1-15, Landes Biosciences, ISBN 978-158706-009-0, Georgetown, Texas, USA.

Oliver, J.D. (2005). Viable but Nonculturable Bacteria in Food Environments. In: Food Borne Pathogens: Microbiology and Molecular Biology, P.M. Fratamico \& A.K. Bhunia (Eds.), 99-112, Horizon Scientific Press, ISBN: 978-1-898486-52-7, Norfolk, United Kingdom

Oliver, J.D. \& Bockian, R. (1995). In Vivo Resuscitation, and Virulence Towards Mice, of Viable but Nonculturable Cells of Vibrio vulnificus. Applied and Environmental Microbiology, Vol.61, No.7, (July 1995), pp. 2620-2623, ISSN 0099-2240

Porter, J., Edwards, C. \& Pickup, R.W. (1995). Rapid Assessment of Physiological Sstatus in Escherichia coli Using Fluorescent Probes. Journal of Applied Bacteriology, Vol.79, No.4, (October 1995), pp. 399-408, ISSN 1364-5072

Quirós, C., Herrero, M., Garcia, L.A. \& Diaz, M. (2009). Quantitative Approach to Determining the Contribution of Viable-butnonculturable Subpopulations of 
Malolactic Fermentation Processes. Applied and Environmental Microbiology Vol.75, No.9, (May 2009), pp. 2977-2981, ISSN 0099-2240

Reissbrodt, R., Rienaecker, I., Romanova, J.M., Freestone, P.P.E., Haigh, R.D., Lyte, M., Tschäpe, H. \& Williams, P.H. (2002). Resuscitation of Salmonella enterica Serovar Typhimurium and Enterohemorrhagic Escherichia coli from the Viable but Nonculturable State by Heat-stable Enterobacterial Autoinducer. Applied and Environmental Microbiology, Vol.68, No.10, (October 2002), pp. 4788-4794. ISSN 0099-2240

Rockabrand, T.A., Arthur, T., Korinek, G., Livers, K. \& Blum, P. (1995). An Essential Role for the Escherichia coli DnaK Protein in Starvation-induced Thermotolerance, $\mathrm{H}_{2} \mathrm{O}_{2}$ Resistance, and Reductive Division. Journal of Bacteriology, Vol.177, No.13, (July 1995), pp. 3695-3703, ISSN 0021-9193

Rowan, N.J. (2011). Defining Established and Emerging Microbial Risks in the Aquatic Environment: Current Knowledge, Implications, and Outlooks. International Journal of Microbiology, Vol.2011, (n.d.), pp. 1-15, ISSN 1687-918X

Servais, P., Prats, J., Passerat, J. \& Garcia-Armisen, T. (2009). Abundance of Culturable versus Viable Escherichia coli in Freshwater. Canadian Journal of Microbiology, Vol.55, No.7, (July 2009), pp. 905-909, ISSN 0008-4166

Shleeva, M., Mukamolova, G.V., Young, M., Williams, H.D. \& Kaprelyants, A.S. (2004). Formation of 'Non-culturable' Cells of Mycobacterium smegmatis in Stationary Phase in Response to Growth under Suboptimal Conditions and Their Rpf-mediated Resuscitation. Microbiology, Vol.150, No.6, (June 2004), pp. 1687-1697, ISSN 1350-0872

Signoretto, C., Lleò, M.M., Tafi, M.C. \& Canepari, P. (2000). Cell Wall Chemical Composition of Enterococcus faecalis in the Viable but Nonculturable State. Applied and Environmental Microbiology, Vol.66, No.5, (May 2000), pp. 1953-1959, ISSN 0099-2240

Signoretto, C., Lleò, M.M. \& Canepari, P. (2002). Modification of the Peptidoglycan of Escherichia coli in the Viable but Nonculturable State. Current Microbiology, Vol.44, No.2, (February 2002), pp. 125-131, ISSN 0343-8651

Spence, J., Cegielska, A. \& Georgopoulos, C. (1990). Role of Escherichia coli Heat Shock Proteins DnaK and HtpG (C62.5) in Response to Nutritional Deprivation. Journal of Bacteriology, Vol.172, No.12, (December 1990), pp. 7157-7166, ISSN 0021-9193

Sperandio, V., Torres, A.G., Jarvis, B., Nataro, J.P. \& Kaper, J.B. (2003). Bacteria-host Communication: the Language of Hormones. Proceedings of the National Academy of Sciences, Vol.100, No.15, (July 2003), pp. 8951-8956, ISSN 0027-8424

Sun, F., Chen, J., Zhong, L., Zhang, X.-H., Wang, R., Guo, Q. \& Dong, Y. (2008). Characterization and Virulence Retention of Viable but Nonculturable Vibrio harveyi. FEMS Microbiology Ecology , Vol.64, No.1, (April 2008), pp. 37-44, ISSN 0168-6496

Terpeluk, C., Goldmann, A., Bartmann, P. \& Pohlandt, F. (1992). Plesiomonas shigelloides Sepsis and Meningoencephalitis in a Neonate. European Journal of Pediatrics. Vol.151, No.7, (July 1992), pp. 499-501, ISSN 0340-6199

Thomas, J.E., Gibson, G., Darboe, M., Dale, A. \& Weaver L.T. (1992). Isolation of Helicobacter pylori from Human Faeces. Lancet, Vol.340, No.8829, (November 1992), pp. 10941095, ISSN 0140-6736

WHO. (2005). WHO Outbreak Communication Guidelines. Available at: www.who.int/infectious-diseasenews/IDdocs/whocds200528/whocds200528en.pdf. 
Xu, H.S., Roberts, N., Singleton, F.L., Attwell, R.W., Grimes, D.J. \& Colwell, R.R. (1982). Survival and Viability of Nonculturable Escherichia coli and Vibrio cholerae in the Estuarine and Marine Environment. Microbial Ecology, Vol.8, No.4, (December 1982), pp. 313-323, ISSN: 0095-3628

Yaron, S. \& Matthews, K. (2002). A Reverse Transcriptase-polymerase Chain Reaction Assay for Detection of Viable Escherichia coli O157:H7: Investigation of Specific Target Genes. Journal of Applied Microbiology, Vol.92, No.4, (April 2002), pp. 633-640, ISSN 1364-5072

Zimmerman, A.M., Rebarchik, D.M., Flowers, A.R., Williams, J.L. \& Grimes, D.J. (2009). Escherichia coli Detection Using mTEC Agar and Fluorescent Antibody Direct Viable Counting on Coastal Recreational Water Samples. Letters in Applied Microbiology, Vol.49, No.4, (October 2009), pp. 478-483, ISSN 0266-8254 


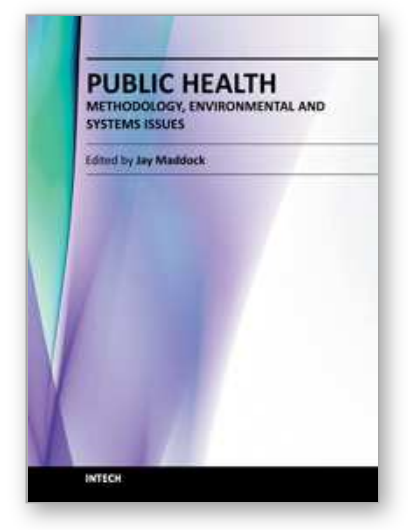

\author{
Public Health - Methodology, Environmental and Systems Issues \\ Edited by Prof. Jay Maddock
}

ISBN 978-953-51-0641-8

Hard cover, 432 pages

Publisher InTech

Published online 30, May, 2012

Published in print edition May, 2012

Public health can be thought of as a series of complex systems. Many things that individual living in high income countries take for granted like the control of infectious disease, clean, potable water, low infant mortality rates require a high functioning systems comprised of numerous actors, locations and interactions to work. Many people only notice public health when that system fails. This book explores several systems in public health including aspects of the food system, health care system and emerging issues including waste minimization in nanosilver. Several chapters address global health concerns including non-communicable disease prevention, poverty and health-longevity medicine. The book also presents several novel methodologies for better modeling and assessment of essential public health issues.

\title{
How to reference
}

In order to correctly reference this scholarly work, feel free to copy and paste the following:

Marco Sebastiano Nicolò and Salvatore Pietro Paolo Guglielmino (2012). Viable but Nonculturable Bacteria in Food, Public Health - Methodology, Environmental and Systems Issues, Prof. Jay Maddock (Ed.), ISBN: 978953-51-0641-8, InTech, Available from: http://www.intechopen.com/books/public-health-methodologyenvironmental-and-systems-issues/viable-but-not-culturable-bacteria-in-food

\section{INTECH}

open science | open minds

\section{InTech Europe}

University Campus STeP Ri

Slavka Krautzeka 83/A

51000 Rijeka, Croatia

Phone: +385 (51) 770447

Fax: +385 (51) 686166

www.intechopen.com

\section{InTech China}

Unit 405, Office Block, Hotel Equatorial Shanghai

No.65, Yan An Road (West), Shanghai, 200040, China

中国上海市延安西路65号上海国际贵都大饭店办公楼405单元

Phone: +86-21-62489820

Fax: +86-21-62489821 
(C) 2012 The Author(s). Licensee IntechOpen. This is an open access article distributed under the terms of the Creative Commons Attribution 3.0 License, which permits unrestricted use, distribution, and reproduction in any medium, provided the original work is properly cited. 